\title{
Zinc and Copper Status of Beef Cattle in the Sumava Region, Czech Republic
}

\author{
P. SLAVÍK ${ }^{1}$, J. ILLEK ${ }^{2}$, T. ZELENÝ 3 \\ ${ }^{1}$ Department of Animal Nutrition, ${ }^{2}$ Clinic of Ruminant Diseases, University of Veterinary and Pharmaceutical \\ Sciences, Brno, Czech Republic \\ ${ }^{3}$ Veterinary Centre, Sušice, Czech Republic \\ Received February 7, 2006 \\ Accepted June 30, 2006
}

\begin{abstract}
Slavík P., J. Illek, T. Zelený: Zinc and Copper Status of Beef Cattle in the Sumava Region, Czech Republic. Acta Vet. Brno 2006, 75: 485-488.

The aim of the study was to ascertain copper $(\mathrm{Cu})$ and zinc $(\mathrm{Zn})$ status in beef cattle in different stages of production pastured in a mountainous area with known soil deficiency of $\mathrm{Zn}$ and $\mathrm{Cu}$. Data from seven beef herds $(n=100)$ were evaluated, each time for two production stages (cows in late pregnancy and heifers). Serum levels of zinc and copper were measured. Mean concentrations of $\mathrm{Zn}$ and $\mathrm{Cu}$ were $16.34+/-3.52 \mu \mathrm{mol} \cdot \mathrm{l}^{-1}$ and $11.17+/-3.27 \mu \mathrm{mol} \cdot \mathrm{l}^{-1}$, respectively. Mean values measured in the heifers $(n=50)$ were $16.3+/-3.58 \mu$ mol. $1^{-1}$ for zinc and $11.65+/-3.32 \mu \mathrm{mol} \cdot 1^{-1}$ for copper. In the cows in late pregnancy $(\mathrm{n}=50)$, serum concentrations of $\mathrm{Zn}$ and $\mathrm{Cu}$ were $16.37+/-$ $3.46 \mu \mathrm{mol} \cdot \mathrm{l}^{-1}$ and $10.68+/-3.07 \mu \mathrm{mol} \cdot \mathrm{l}^{-1}$, respectively. Neither for copper $(p<0.59)$ nor for zinc $(p<0.99)$ significant differences were demonstrated between cows in late pregnancy and heifers. Moreover, analysis of their feed revealed that the content of these minerals was half of the recommended levels. Therefore, to achieve an adequate zinc status, both cattle categories pastured in this area should have access to mineral licks.
\end{abstract}

Cattle, zinc, copper, beef cattle

Zinc is important for the synthesis of proteins and nucleic acids, formation of skin structures, skeleton metabolism, and energy metabolism. In ruminants, it plays an important role in rumen fermentation processes, mainly cellulose digestion and formation of volatile fatty acids (VFA) (Underwood and Suttle 1999; O’Dell 2000; Cao et al. 2000).

Zinc is absorbed by simple diffusion. Having entered the intestinal mucosa cells, it is bound to metallothionein, which ensures its transport across the intestinal wall to blood circulation. Zinc absorption is reduced by oxalates, tannin, and excessive levels of $\mathrm{Cu}, \mathrm{Fe}$, Cd (Hara 2000; Lonerdal 2000). At present, the occurrence of deficiencies in milked cows does not exceed 10\% (Pavlata et al. 2005). However, the occurrence of $\mathrm{Cu}, \mathrm{Fe}$ and $\mathrm{Cd}$ deficiencies is much higher in fattening calves and bulls (15-20\%). $\mathrm{Zn}$ is located mainly in the bone tissue, central nervous system (CNS), erythrocytes, muscle, pancreas, kidneys and spleen. There are no specific locations of zinc reserves (Benich 1990; LopezAlonso et al. 2005). The physiological range of plasma zinc in cattle is $12-18 \mu \mathrm{mol} \cdot \mathrm{l}^{-1}$ (Underwood and Suttle 1999). Zinc requirement in cattle is $40 \mathrm{mg} \cdot \mathrm{kg}^{-1}$ dietary dry matter (NRC 2001).

Copper absorption takes place in the stomach and small intestine. Copper entering the gastrointestinal cells is bound by metallothionein that lowers the speed of transport from the cells to the body. The absorption is reduced from $75 \%$ at a $\mathrm{Cu}$ intake of $0.4 \mathrm{mg}$ per day to $12 \%$ at a $\mathrm{Cu}$ intake of $7.5 \mathrm{mg} \mathrm{Cu}$ per day. After the absorption, copper is trapped by the liver and kidneys. There, it is incorporated in ceruloplasmin and metallothionein. From ceruloplasmin it is released in to the circulation and transported to cells. Copper is excreted via bile (Underwood and Suttle 1999). In the body it contributes to the integrity of connective issue, corrects the pancreas function, hem formation, and influences the myelin

Address for correspondence:

MVDr. Petr Slavík

University of Veterinary and Pharmaceutical Sciences

Palackého 1-3, Brno

61242 Czech Republic

Phone: +420541562 679; +420607 727743

E-mail: slavik.pe@seznam.cz

http://www.vfu.cz/acta-vet/actavet.htm 
formation. $\mathrm{Cu}$ deficiency symptoms include defects in hair coat pigmentation, liver disorders, anaemia, and leucopoenia. For the determination of copper status, $\mathrm{Cu}$ and ceruloplasmin levels in plasma or serum, or $\mathrm{Cu}$ levels in body organs are measured (Lopez-Alonso et al. 2005). The physiological range of plasma $\mathrm{Cu}$ is $12-16 \mu \mathrm{mol} \cdot \mathrm{l}^{-1}$ (Underwood and Suttle 1999). The NRC (2001) recommended $10 \mathrm{mg} \mathrm{Cu}$ per kg DM in the diet.

The aim of the study was to determine copper and zinc serum concentrations in beef cows and heifers in selected herds reared in a mountainous region.

\section{Materials and Methods}

Šumava is a border region and cattle are reared extensively there, mainly in pastures deficient in trace elements. Seven beef cattle herds including different breeds $(n=100)$ were monitored and analysed in the spring of 2004. In each herd, blood was collected from 8 (herds 1 - 4) or 6 (herds 5 - 7) heifers and 8 (herds 1 - 4) or 6 (herds 5 - 7) cows in late pregnancy.

In all the herds, animals had access to a mineral lick ( $4 \mathrm{~g} \mathrm{Zn} / \mathrm{kg}$ lick; no copper) for most of the year. In some herds, mineral supplement of unknown composition was provided at irregular intervals.

Blood was withdrawn from both the heifers and the cows in late pregnancy $\left(8^{\text {th }}\right.$ to $9^{\text {th }}$ month of pregnancy). In the summer, all the animals grazed only without additional feeding. The winter diet consisted of grass silage and hay. In some herds, cows around calving received small amounts of maize silage. The winter diet contained 24.20 $\mathrm{mg} \mathrm{Zn/kg} \mathrm{DM} \mathrm{and} 4.59 \mathrm{mg} \mathrm{Cu} / \mathrm{kg} \mathrm{DM}$, on average.

Blood collections were always carried out at the same time. Blood was collected from the coccygeal vein, using the HEMOS ${ }^{\circledR}$ system, transported to the laboratory and analysed using the hydride method and by the atomic absorption spectrophotometer (AAS) SOLAR 939.

Results were processed by Microsoft Excel. Mean values (x) and standard deviation (S.D.) values are given in tables.

\section{Results and Discussion}

Mean concentrations of $\mathrm{Zn}$ and $\mathrm{Cu}$ in blood samples of all animals $(\mathrm{n}=100)$ were $16.34 \pm 3.52 \mu \mathrm{mol} \cdot \mathrm{l}^{-1}$ and $11.17 \pm 3.27 \mu \mathrm{mol} \cdot \mathrm{l}^{-1}$, respectively. Mean values of $\mathrm{Zn}$ in the heifers $(\mathrm{n}=50)$ were $16.3 \pm 3.58 \mu \mathrm{mol} \cdot \mathrm{l}^{-1}$ and $11.65 \pm 3.32 \mu \mathrm{mol} \cdot \mathrm{l}^{-1}$, respectively, and in the cows in late pregnancy $(\mathrm{n}=50) 16.37 \pm 3.46 \mu \mathrm{mol} \cdot \mathrm{l}^{-1}$ and $10.68 \pm 3.07 \mu \mathrm{mol} \cdot \mathrm{l}^{-1}$, respectively, see Fig. 1 and Fig. 2. Mean Zn levels in different herds are listed in Table 1; mean Cu levels

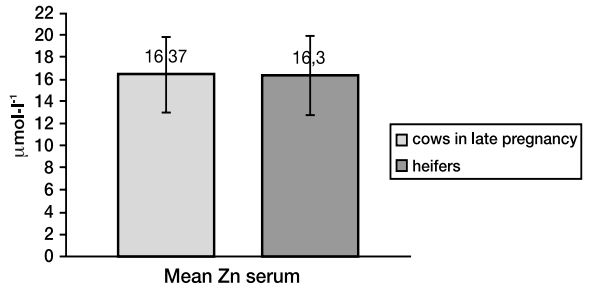

Fig. 1. Mean $\mathrm{Zn}$ concentration in blood serum of cows and heifers of all herds under study.

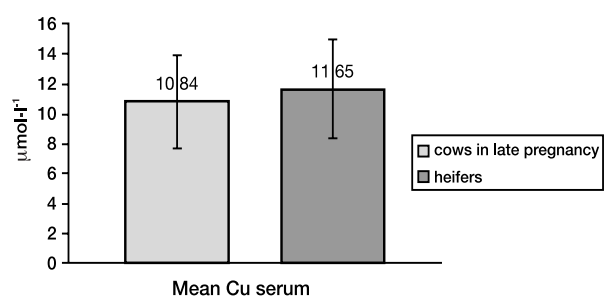

Fig. 2. Mean $\mathrm{Cu}$ concentration in blood serum of cows and heifers of all herds under study.

in Table 2. The data in both tables show that zinc status in the animals under study was sufficient, although its content in feed $(24.20 \mathrm{mg} / \mathrm{kg} \mathrm{DM})$ was about a half of the recommended level of $50 \mathrm{mg} / \mathrm{kg}$ DM (NRC 2001). Unlike Biesalski and Grimm (1999), we did not find a significant difference between mean concentrations of $\mathrm{Zn}$ in the pregnant cows and the heifers $(p<0.99)$. When comparing mean values between these production stages in some herds, differences were obvious but no ultimate conclusion can be drawn. 
Table 1. Mean $\mathrm{Zn}$ levels in the herds under investigation

\begin{tabular}{|c|c|c|c|c|c|c|}
\hline & Herd No. & $\mathrm{x}$ & S.D. & $\min$. & $\max$ & $\mathrm{n}$ \\
\hline \multirow{7}{*}{$\begin{array}{l}\text { Cows in late } \\
\text { pregnancy }\end{array}$} & 1 & 19.52 & 3.52 & 14.96 & 25.36 & 8 \\
\hline & 2 & 14.93 & 1.56 & 11.1 & 16.04 & 8 \\
\hline & 3 & 19.03 & 4.55 & 14.67 & 24.6 & 8 \\
\hline & 4 & 14.54 & 1.7 & 12.66 & 16.4 & 8 \\
\hline & 5 & 18.06 & 1.26 & 16.3 & 20.16 & 6 \\
\hline & 6 & 13.07 & 1.52 & 11.82 & 16.24 & 6 \\
\hline & 7 & 15.02 & 2.21 & 12.56 & 19.56 & 6 \\
\hline \multirow{7}{*}{ Heifers } & 1 & 22.12 & 2.98 & 15.52 & 27.6 & 8 \\
\hline & 2 & 15.87 & 0.93 & 14.49 & 17.31 & 8 \\
\hline & 3 & 14.96 & 1.0 & 12.55 & 16.4 & 8 \\
\hline & 4 & 14.56 & 2.95 & 11.22 & 19.13 & 8 \\
\hline & 5 & 18.69 & 0.83 & 17.7 & 19.95 & 6 \\
\hline & 6 & 12.98 & 0.60 & 12.42 & 14.21 & 6 \\
\hline & 7 & 14.93 & 0.82 & 13.8 & 16.5 & 6 \\
\hline
\end{tabular}

Copper status in the animals under study was rather marginal or there was copper deficiency found in herds No. 4, 6, 7 (where animals were provided only mineral licks). Mean $\mathrm{Cu}$ content in feed was about a half of the one recommended by NRC $(10 \mathrm{mg} / \mathrm{kg} \mathrm{DM})$. Similar results were reported by Govas mark et al. (2005), who monitored the situation in Scandinavia and Kováč et al. (2003) in Eastern Slovakia. Because the mineral lick did not contain copper, the diet was the only source of this mineral. Mean concentration of $\mathrm{Cu}$ in late pregnancy cows $\left(10.84 \mu \mathrm{mol} \cdot \mathrm{l}^{-1}\right)$ was lower than in the heifers $\left(11.65 \mu \mathrm{mol} \cdot \mathrm{l}^{-1}\right)$, but no significant differences were found $(p<0.59)$.

Table 2. Mean $\mathrm{Cu}$ levels in the herds under investigation

\begin{tabular}{|c|c|c|c|c|c|c|}
\hline & Herd No. & $\mathrm{x}$ & S.D. & $\min$. & $\max$ & $\mathrm{n}$ \\
\hline \multirow{7}{*}{$\begin{array}{l}\text { Cows in late } \\
\text { pregnancy }\end{array}$} & 1 & 12.82 & 1.04 & 11.04 & 14.62 & 8 \\
\hline & 2 & 11.53 & 3.38 & 10.19 & 13.92 & 8 \\
\hline & 3 & 12.81 & 1.9 & 9.61 & 16.35 & 8 \\
\hline & 4 & 10.54 & 2.1 & 5.72 & 13.37 & 8 \\
\hline & 5 & 13.32 & 2.69 & 9.14 & 16.3 & 6 \\
\hline & 6 & 8.19 & 1.69 & 5.39 & 10.11 & 6 \\
\hline & 7 & 6.7 & 0.41 & 6.04 & 7.19 & 6 \\
\hline \multirow{7}{*}{ Heifers } & 1 & 12.14 & 1.15 & 10.32 & 14.6 & 8 \\
\hline & 2 & 13.73 & 3.78 & 10.2 & 17.02 & 8 \\
\hline & 3 & 14.51 & 1.35 & 12.05 & 16.36 & 8 \\
\hline & 4 & 14.27 & 1.78 & 12.4 & 18.26 & 8 \\
\hline & 5 & 11.43 & 1.44 & 8.68 & 13.22 & 6 \\
\hline & 6 & 8.33 & 1.87 & 6.59 & 11.52 & 6 \\
\hline & 7 & 7.16 & 1.57 & 4.8 & 10 & 6 \\
\hline
\end{tabular}

The results of this study show that in order to achieve an adequate or marginal zinc status in cattle, it is sufficient for them to receive $\mathrm{Zn}$ from mineral lick. When it comes to copper status, we can draw a conclusion that $\mathrm{Cu}$ provision by the diet was insufficient and $\mathrm{Cu}$ supplementation from mineral lick was necessary. However, the pursuit of preventive diagnostic tests in beef cattle herds is important for the assessment of the herd health status (Kováč et al. 2004). 


\section{Zásobení zinkem a mědí u krav masných plemen v regionu Šumava v České republice}

Cílem studie bylo zjistit stav zásobení mědí a zinkem různých kategorií zvířat u masného skotu chovaného v regionu Šumava. V rámci našeho sledování byly vyhodnoceny výsledky v sedmi chovech masného skotu $(n=100)$ vždy u dvou kategorií zvířat (vysokobřezí krávy a jalovice). Stanoven byl zinek a měd' v krevním séru. Průměrná koncentrace Zn činila $16,335( \pm 3,52) \mu \mathrm{mol} \cdot \mathrm{l}^{-1} \mathrm{a} \mathrm{Cu} 11,17( \pm 3,27) \mu \mathrm{mol} \cdot \mathrm{l}^{-1}$. Průměr u jalovic $(\mathrm{n}=50)$ byl v př́ípadě

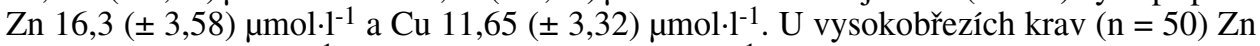
$16,37( \pm 3,46) \mu \mathrm{mol} \cdot 1^{-1}$ a $\mathrm{Cu} 10,68( \pm 3,07) \mu \mathrm{mol} \cdot \mathrm{l}^{-1}$. Statisticky významný rozdíl mezi vysokobřezími kravami a jalovicemi se jak v případě mědi $(p<0,59)$, tak v prrípadě zinku $(p<0,99)$ prokázat nepodařilo. Výsledky ukázaly, že koncentrace těchto minerálních látek v pastevním porostu, senu a senáži ve sledovaných chovech byla nízká. Průměrná koncentrace zinku v objemné píci činila $24,19 \mathrm{mg} / \mathrm{kg}$ sušiny, koncentrace mědi 4,59 mg/kg sušiny. Minerální lizy s obsahem zinku vyrovnaly jeho deficit. Dotace mědi nebyla předkládaným lizem ovlivněna. Zásobení mědí bylo marginální či karenční.

\section{Acknowledgements}

The study was supported by the Ministry of Agriculture of the Czech Republic (grant No. QF 4005).

\section{References}

BENICH A 1990: Antioxidant micronutrients and immune responses. Ann New York Acad Sci 587: 168-180

BIESALSKI HK, GRIMM P 1999: Taschenatlas der Ernährung. Georg Thieme Verlag, Stuttgart, pp. 342.

CAO J, HENRY PR, GUO R, HOLWERDA RA, TOTH JP, LITTELL RC, MILES RD, AMMERMAN CB 2000: Chemical characteristics and relative bioavailability of supplemental organic zinc sources for poultry and ruminants. J Anim Sci 78: 2039-2054

GOVASMARK E, STEEN A, BAKKEN AK, STROM T, HANSEN S, BERNHOFT A 2005: Copper, molybdenum and cobalt in herbage and ruminants from organic farms in Norway. Acta Agr Scand Sect A-Anim Sc 55: $21-30$

HARA H, KONISHI A, KASAI T 2000: Contribution of the cecum and colon to zinc absorption in rats. J Nutr 130: 83-89

KOVÁČ G, NAGY O, SEIDEL H, JESENSKÁ M, HIŠČÁKOVÁ M, ZACHAR P, HISIRA V 2003: The status of macro and microelements in the blood serum, milk, rumen fluid, faeces and urine in a farm with increasing milk production. Folia Vet 47: 124-129

KOVÁĆ G, NAGY O, SEIDEL H, REICHEL P, HISIRA V, NOVOTNÝ J 2004: The importance of preventive diagnosis in a dairy farm with increasing milk production. Folia Vet 48: 206-212

LONERDAL B 2000: Dietary factors influencing zinc absorption. J Nutr 130 (5S Suppl.): 1378-1383

LOPEZ-ALONSO M, PRIETO F, MIRANDA M, CASTILLO C, HERNANDEZ JR, BENEDITO JL 2005 : Intracellular distribution of copper and zinc in the liver of copper-exposed cattle from northwest Spain. Vet J 170: 332-338

NRC 2001: Nutrient Requirements of Domestic Animals, Nutrient Requirements of Dairy Cattle. $7^{\text {th }}$ ed. National Academy of Sciences, Washington, DC.

O’DELL BL 2000: Role of zinc in plasma membrane function. J Nutr 130 (5S Suppl.): 1432-1436

PAVLATA L, PODHORSKÝ A, PECHOVÁ A, CHOMÁT P 2005: Differences in the occurrence of selenium, copper and zinc deficiencies in dairy cows, calves, heifers and bulls. Vet Med-Czech 50: 390- 400

UNDERWOOD EJ, SUTTLE NF 1999: The mineral nutrition of livestock. $3^{\text {rd }}$ ed., CABI Publishing, pp. 614-642 